\title{
Use of E-mail Dialogue Journal in Enhancing Writing Performance
}

\author{
Maryam Foroutan ${ }^{1}$, Nooreen Noordin ${ }^{1} \&$ Mohd Sahandri Gani bin Hamzah ${ }^{2}$ \\ ${ }^{1}$ Department of Language and Humanities Educaton, Universiti Putra Malaysia (UPM), Malaysia \\ ${ }^{2}$ Sultan Idris Education University, Tanjung Malim, Perak Darul Ridzuan, Malaysia \\ Correspondence: Maryam Foroutan, Department of Language and Humanities Educaton, Universiti Putra \\ Malaysia (UPM), Malaysia. E-mail: M_foroutan2007@yahoo.com
}

Received: January 3, 2013 Accepted: April 11, 2013 Online Published: June 1, 2013

doi:10.5539/ass.v9n7p208 URL: http://dx.doi.org/10.5539/ass.v9n7p208

\begin{abstract}
In the age of computer mediated technology, the effects of the internet applications on learners' performance have been broadly investigated by many researchers. In keeping with this trend, this study compared the effect of conventional tools as pen-and-paper, and e-mail, on the writing performance in terms of content, organization, language use, vocabulary and mechanics. Forty two English major students from one intact class at Universiti Putra Malaysia (UPM), based on their grades in "Expository Writing", as a subject taken in the previous semester, were randomly assigned into two groups, namely: pen-and-paper dialogue journal and e-mail dialogue journal. Pre and post writing tests were administered to identify two groups' differences in their writing performance scores. After going through seven week intervention, quantitative research results revealed that e-mail group outperformed their counterparts in overall writing performance and language use, one of the categories. However, for other writing performance components, this research showed no significant difference between groups. With the empirical data offered in this study, e-mail can be applied as a suitable tool to assist language learner to improve their writing performance.
\end{abstract}

Keywords: e-mail, computer-mediated communication (CMC), writing performance, dialogue journal writing, learner-centered approach, motivation

\section{Introduction}

With the evolving world of technology, we are witnessing dramatic growth in the number of learners using the internet as an essential study aid in their daily lives. The internet has been welcomed by many educators where it has brought undeniable opportunities in second language teaching and learning. Computer-mediated communication (CMC), as a viable and potentially helpful alternative in the classroom, provides authentic material in the second language learning and teaching context. E-mail as "the mother of all internet applications" (Warschauer, Shetzer \& Meloni, 2000: 3) has gathered momentum among researchers and is recognized as one of the most successful computer applications (Whittaker \& Sidner, 2000); nevertheless, it has not received much attention in the language learning literature. Electronic communication due to its potential in moving in time and space supersedes the limitations of face to face delivery and has been regarded as a trustable source of information especially for students (Krajka, 2002).

Although it is generally agreed that e-mail conveys many potential advantages in ESL classes, only few studies (Albakri et al., 2003; Gonzalez-Bueno \& Perez, 2000; Wang, 1998) have measured the effect of e-mail dialogue journals on writing performance in ESL context and it seems that this tool is not fully utilized in second language learning. There is a paucity of research on how e-mail can assist language learners to improve their writing performance. Thus, more research-based studies needed to assure educators and lecturers in utilizing e-mail as a supplementary tool.

\section{Purpose of the Study}

Students generally find writing a very demanding skill and feel anxious in the writing tasks. One of the reasons is that writing task requires more elaboration and clarity compared to other skills. Writing teachers commonly do not look for the appropriate methods to facilitate students' writing processes; instead correct their grammatical errors which this results in anxiety and students' unwillingness to write (Garlikov, 2000).

To pave the way for learners, communicative approach in ESL classes brought interest in using communicative 
context simulating real life interaction in which its emphasis is not on form but on real communication. It is acclaimed that this approach, apart from providing enthusiasm among learners, can facilitate their learning (Yen-Ren, 1996). Sakura (2001) pointed out to the primary objective of communicative language teaching as "the ability not only to communicate using rules of grammar, but also to use language appropriate in social contexts and to employ verbal and nonverbal strategies to overcome breakdowns in communication" (p. 8).

Dialogue journal writing, as one of the communicative methods, apart from providing natural setting for literacy improvement (Peyton, 2000), has been introduced as a method to enhance interaction, increase participation and communication among learners (Peyton, 1990; Peyton \& Reed, 1990). The study of literature (Peyton \& Reed, 1990; Song, 1997; Reid, 1997; Holmes \& Moulton, 1997; Peyton, 1984) shows students' satisfaction and lower anxiety, besides improvement in writing quality when they write about topics of their interest.

E-mail especially in the context of a dialogue journal has been regarded as a valuable tool which facilitates communication; meanwhile, provides dyadic opportunities for learner in a non-threatening environment. E-mail and dialogue journal together seem like the perfect mode in decreasing anxiety (Foroutan \& Nooreen, 2012) and improving writing performance (Albakri et al., 2003; Wang, 1998).

By considering the benefits of integrating e-mail as an Internet tool in writing classes especially for writing dialogue journals, more research-based studies are required to compare e-mail with pen-and-paper in writing dialogue journal to investigate the effect of e-mail dialogue journal writing on students' writing skills. This is seen as a useful way in encouraging and ensuring ESL teachers to utilize electronic writing tools in their writing classes. This research, therefore, addressed to the following main objective:

To determine the effect of e-mail dialogue journal writing and pen-and-paper dialogue journal writing on ESL students' writing performance.

The specific objectives are:

1) To measure the effects of e-mail dialogue journal and pen-and-paper dialogue journal on students' overall writing performance by comparing the posttest scores of two groups.

2) To measure the effects of e-mail dialogue journal writing and pen-and-paper dialogue journal writing on students' writing performance by comparing the posttest scores of two groups based on five main categories: content, organization, vocabulary, language use and mechanics.

\section{Review of the Literature}

\subsection{Computer-Mediated Communication (CMC)}

With their various applications and their increasing popularity, the role of computers in education has been increasingly documented by researchers. Extensive research has been conducted into possible effects of using computer to language learning. The reasons for the increasing interest to use technology in the classes, can be related to the fast changes that technology has brought to human life and to the innovative methods of teaching languages which are constantly developing (Wolff, 1999).

One of the aspects of using computers in language learning refers to Computer-Mediated Communication (CMC). CMC relates to the use of specific local area network software programs (LAN), or online communication via the internet for language teaching (Warschauer, 1996). Romiszowski and Mason (2004) describe $\mathrm{CMC}$ as the procedure by which people compose, interchange, and apprehend information while using networked telecommunication systems that make encoding, transmitting, and decoding messages easier.

Kitao (1998) refers to two main forms of communication in the internet as: synchronous and asynchronous communication. Synchronous communication, e.g., chat, happens in real time when user logs in and directly communicates with others, whereas asynchronous communication, such as: e-mail and bulletin boards, have a delayed message system (Warschauer \& Healey, 1998). Chen, Liu, and Wong (2007) believe that participants who are issued with asynchronous media are more autonomous, have more freedom in picking the time for their participation and have more access to learning supports. Moreover, asynchronous methods can facilitate learning by "providing a central repository for information storage" for the learners (p. 221).

Undeniably, the spectacular environment provided by CMC allows ESL learners to virtually leave the boundaries of their classrooms where by providing international communication (Soh \& Soon, 1991) and cooperative learning, they have the chance to improve their foreign language performance and skills (Hung, 2007; Abrams, 2003). CMC offers less threatening means to communicate, increases students' motivation and decreases anxiety (Kroonenberge, 1994/1995; Wang, 1998; Kern, 1995; Foroutan et al., 2012). Students who use the internet begin to understand that besides connecting to the world and doing research in English, the internet is no on longer 
considered as a hobby, but an essential skill to be applied in a real life context (Fox, 1998).

According to Gonzalez-Bueno and Perez (2000), the importance of CMC lies in its ability to produce the language which is text-based; hence it caters advantages for language learning, where it offers the writer the opportunity for revision and writing accurately. In short, CMC has reformed the methods in writing, sending and receiving information, and also the way we teach and learn (Warschauer, 2004; Barker, 2002; Warschauer, 2002).

\subsection{Computer Assisted Writing in ESL Context}

The history of using computers in writing classes traces back to the 1980s. The presence of computers in North American schools, universities and colleges triggered limitless enthusiasm among writing researchers to investigate the effect of applying the word-processing and other writing tools on students' writing outcomes. In this way, Computer Assisted Writing researchers for many years have tried to pave the way for writing teachers in applying new writing technologies in their classes. In spite of this, research has shown many controversial results in using computers to teach writing. On the one hand, some research findings show evidence that analyzers sometime misguide the writers in using the correct form of grammar, thus the use of these features by novice writers in the methods of thinking, planning or revising is not suggested (Ferris \& Hedgcock, 2005).

On the other hand, using computers have been reported to benefit writers. The use of computers facilitates peer interaction and collaborative activities, improve students' motivation and participation especially for novice writers (Sullivan and Pratt, 1996). Research shows that those students who used word processors, spent more time in writing, produced longer texts (Burley,1994; Hawisher \& Fortune,1988) and more error-free texts as compared to pen and paper users (Cochran,1991). Research (such as; Dauite, 1986; Vacc, 1987) showed that when students write on the computer, they are interested to write and revise their writing more often.

\subsection{Theories to Support CMC}

\subsubsection{Constructivism Theory}

Based on constructivism theory, learning activities should encompass the real world, worthwhile results and authentic experiences (Mynard, 2003). Hein (1991) outlined some of the constructivism principles as:

1) Learning is an active process through which the learner should be engaged in the activity and the world.

2) Learning happens through learning.

3) Learning embraces social connections with human beings, peers, teachers, and family. In traditional education, the learner is separated from social interaction, but nowadays, education counts on the role of interaction in learning.

4) Learning new knowledge happens based on the previous knowledge.

5) Learning is a process which needs time.

Two main principles in Vygotsky's cognitive development theory are interaction and conversation. Students have to overcome their difficulties by the scaffolding which can be obtained through interaction with teacher or other students (Woolfolk, 2007).

$\mathrm{CMC}$ encompasses rich environment with ample materials, thereby learners can explore and understand information in an active way. In addition, $\mathrm{CMC}$ has the potential in providing the element of incorporation among peers and teacher-students which has conformity with constructivist theory (Ohlund, 1997).

\subsubsection{Affective Filter Hypothesis}

Motivation, self-confidence and anxiety, based on Krashen's (1982) theory, greatly contribute to second language acquisition. Having higher motivation and self-confidence will result in lower anxiety; as such second language acquisition will most likely enrich. On the contrary, low motivation and self-esteem and high anxiety will bring about 'mental block' which contributes to 'comprehensive input' deficiency.

\subsubsection{The Learning Acquisition Hypothesis}

Krashen (1982) differentiates 'learning' from 'acquisition' in which 'learning' is the study of the language rules, whereas 'acquisition' is using the language for real communication. Krashen links acquisition to 'universal grammar' through which a child is able to speak grammatically despite getting no instruction from elders.

\subsubsection{The Monitor Hypothesis}

According to this hypothesis (Krashen, 1982) 'acquisition' occurs when we start our statements in the second language and it helps us with our fluency, while learning is just a "monitor or editor" (p. 15). Monitor hypothesis works on three conditions: (a) time: second language learner should have enough time to think about the rules 
and to use them effectively; (b) focus on form: the performer should focus on form and consider the correctness; and (c) know the rule: the performer should know the rules.

\subsubsection{Input Hypothesis}

Krashen's input hypothesis was designed based on Vygotsky's zone of proximal development. Based on this theory, we comprehend and acquire when the input is one level beyond where we are (i+1). Krashen (1982) justifies this paradox as we use our linguistic competence to help us to understand. In addition, we use "our knowledge of the world", "content", and "our extra-linguistic information" to guide us in understanding the language (p. 21). This hypothesis suggests that we first get the meaning and then acquire structure. Another part of this hypothesis states that if the acquirer understands and receives enough input, $i+1$ will be automatically obtained. Krashen highlights that attempts of teachers and students to practice a special grammatical structure to provide $i+1$, is unnecessary and even harmful. He believes that the role of social interaction in language acquisition to provide natural communication for students is very crucial.

Aitsiselmi (1999) regarded e-mail as a suitable representative of Krashen's hypotheses. Considering acquisition as a central phase and learning as secondary, Aitsiselim believes that pedagogical programs should be planned to provide low anxiety situation in a genuine communication for acquiring the target language. This language should be globally comprehensive and the topics should be so stimulating for learners to grab their attention on content rather than form. To this end, e-mail exchanges are suitable means to symbolize this kind of interaction.

In short, dialogue journal writing and CMC including e-mail, as mentioned by so many researchers, possess required components mentioned in Vygotsky's and Krashen's theories. The theories are deemed appropriate to form the bases for the current research.

\section{Methods}

\subsection{Participants}

Subjects were 42 English major undergraduate students, 30 females and 12 males, from one intact class at Universiti Putra Malaysia (UPM), Malaysia. These students, based on their grades in expository writing taken previous semester and gender were randomly assigned into two classes. In the pen-and-paper dialogue journal group, there were 6 males (27.3\%) and 14 females (63.6\%); whereas, in e-mail dialogue journal group, 6 males $(27.3 \%)$ and 16 females $(72.7 \%)$ participated. In general, there were more females in each group. The range in age was 20 to 22 years.

\subsection{Procedure}

Prior to the treatment, a demographic questionnaire was administered to obtain the participants' background information and to get some information about using e-mail and the extent of their familiarity in using this system of communication. After ensuring that students in the e-mail group have enough knowledge in using e-mail, the researcher taught both groups how they were supposed to write dialogue journals to their secret pals and what they had to write about. A pre-test was conducted where participants had to write about the topics given. In the task of writing dialogue journals, different topics, but with the same level of difficulty were given to each group. The following sections explain each group's treatment.

\subsection{Treatment}

Dialogue journal writing via e-mail (Group 1): In the first session, students were taught how they can use the e-mail system. Besides, some techniques, such as; categorizing received e-mails and using draft, were presented to them. In the next stage, students were asked to send instant e-mails to the researcher to both make sure about students' ability in using this system and to give the researcher easier access to the students' e-mail addresses.

Ensured about their ability in using e-mail system, students were divided into dyadic groups to correspond with each other. Instead of their real names, each of them received an ID which was one of the alphabet letters. The reason to have this secret ID was to encourage students to express their feelings and ideas more openly (Worthington, 1997). Choosing one topic among others, students were required to write and share their feeling and ideas with their correspondents. They were asked to write their dialogues for fifteen minutes in the beginning of the class, under the researcher's supervision. The length of the writing was determined with a minimum of three sentences and the maximum was left to the students (as suggested by Peyton, 2000). In order to keep students' anonymity, each student sent his or her e-mail to the researcher's e-mail address and the researcher forwarded it to another student with the same ID in another group. Fifteen minutes before the class ends, participants were asked to reply to their friends' entries. Therefore, each student was supposed to reply to her or his friend's e-mail, i.e. two entries were collected from each student in each session,. Data collection 
continued for seven weeks.

Dialogue journal writing via pen-and-paper (Group 2): The same procedures were conducted for pen-and-paper dialogue journal group. Pen-and-paper participants, the same as e-mail group, were asked to write their dialogue journals based on the suggested topics. Each student received an ID for every session and was asked to write his or her dialogue journal to his/her secret pal by using pen and an A4 paper. Fifteen minutes at the beginning of each session was allocated to writing the dialogue journals. After collecting all papers, fifteen minutes to the end of the class, these entries based on the students' IDs were carefully exchanged so that each student could reply to his or her secret pal. Every session the papers were copied and returned to the students to read their friends' replies. The students were asked to make a profile and keep them for their reference. Each student wrote two dialogue journals in each session. The students' correspondence took seven weeks at the same time with e-mail dialogue journal group.

\subsection{Instrument and Measurement}

The written entries for each group were analyzed using the ESL Composition Profile (Jacobs, Zinkgraf, Wormuth, Hartifel and Hughey, 1981). According to Bailey (1998), this is the most appropriate scale for evaluating ESL writing. Lam and Pennington (1993) also believe that this scale is one of the complete rubrics which is able to assess all important elements of writing. This scoring scale consists of five main features, i.e. content (30\%), organization (20\%), vocabulary (20\%), language use $(25 \%)$, and mechanics $(5 \%)$; each of them form the analytic writing scale. The total score was obtained by adding these points from each writing sample.

\subsection{Validity of the Research}

In this research, as both groups took the same pre- and posttest assessments, and they went through the same period of time, the threats like; maturation, pretesting, history, instrumentation, were not considered as threats to the internal validity. Ary et al. (2002) stress that one of the crucial internal validity threats for quasi-experimental design is selection bias i.e. groups may have not equivalent level of writing proficiency before the treatment starts. Based on Ary, et al.'s suggestion for solving this problem, a pretest was administered and independent-sample t-test was run to determine the differences between pre-tests prior to the treatment. The results showed there was no significant difference between mean scores of two groups on the dependent variables (writing performance scores).

\section{Results and Discussion}

As the main objective of this study was to compare e-mail and pen-and-paper dialogue journal writing in terms of writing performance, t-test was run to compare posttest writing performance mean scores. The results are presented in Table 1.

Table1. The mean and standard deviation for posttest overall writing performance

\begin{tabular}{ccccc}
\hline Group & mean & SD & $t$ & $p$ \\
\hline Pen-and-paper & 76.06 & 7.525 & -2.237 & .023 \\
E-mail & 80.78 & 5.633 & & \\
\hline
\end{tabular}

Table 2. Comparing posttests writing performance components

\begin{tabular}{cccccc}
\hline & group & Mean & SD & $t$ & $p$. \\
\hline \multirow{2}{*}{ Content } & pen-and-paper & 23.03 & 3.067 & -1.676 & .101 \\
& e-mail & 24.45 & 2.449 & & \\
Organization & pen-and-paper & 16.00 & 1.732 & -1.636 & .110 \\
& e-mail & 16.91 & 1.856 & & \\
Vocabulary & pen-and-paper & 15.55 & 2.025 & -1.375 & .177 \\
& e-mail & 16.32 & 1.585 & & \\
Language use & pen-and-paper & 17.55 & 1.877 & -.3755 & .001 \\
& e-mail & 19.52 & 1.523 & & \\
Mechanics & pen-and-paper & 3.78 & .413 & -1.221 & .238 \\
& e-mail & 3.91 & .294 & & \\
\hline
\end{tabular}


As shown in table 1 , e-mail dialogue journal group $(\mathrm{M}=80.78)$ showed higher mean score as compared to pen-and-paper dialogue journal group ( $M=76.06)$. It shows that e-mail dialogue journal group performed better in terms of their post writing scores compared to their counterparts

Based on the results obtained, there was a significant difference $[t(40)=-2.327, p<.05]$ in overall writing performance posttest scores between two groups. The e-mail dialogue journal group outperformed their counterparts in pen-and-paper dialogue journal. This can be due to several factors. One of the possibilities may relate to the students' easier access to the e-mail features through which e-mails can be saved and sorted according to the date, sender and other categories. These features might have enabled the users to review the emails anytime they wished; consequently, these features could have affected their writing performance.

Another possibility for improving writing through e-mail can relate to students' motivation. The students could have been more motivated to read their e-mails during the treatment, to monitor their language production and to have chance to learn from others. Lam and Pennington (1993) claim that writing using a computer is an interesting and stimulating experience for students through which they have the opportunity to learn language and use English in a new way. They added that word-processor users consider process more important than the product of writing; thus, they are more encouraged to brainstorm their ideas and correct their output until the last version. Crystal (2001) also believes that e-mail users have more control over their e-mail compared to other written forms as once they sent the e-mail, they would not have another chance to modify it. Crystal assumes that e-mail users are aware of the medium's informality and try to send their e-mails with intelligence. Likewise, Wang (1998) verifies that as e-mail users are aware of the fact that once they sent the e-mail, they would not have the opportunity to edit or do modifications as oppose to writing on paper, as the result this perception about e-mail causes working on their task more than pen-and-paper version. Consequently, easier access to e-mails, easier correction, having easier access to online dictionaries and motivation to write, might have encouraged e-mail dialogue journal participants to practice and improve their writing performance.

Aitsiselmi (1999) also presents some features in e-mail that enable users to improve their learning. He believes that e-mail inspires students to write as it enables them to logically organize their thoughts. Apart from that, word-processing features in e-mail enable students to brainstorm for ideas easily on the screen without worrying about the structure or grammatical errors. Mistakes can be corrected and be rewritten easily just by typing the words or sentences. In addition, Aitsiselmi points out that by taking part in genuine communication in the target language, e-mail users develop their communicative competency and improve their knowledge of the language structure and grammar without being aware of their learning. He states that subconscious learning is one of the main principles in second language acquisition theory which e-mail communication successfully fits with this principle. To sum up, the obtained results gave empirical evidence to support the claim that e-mail can be used as an efficacious and instructional aid to teach and learn writing skills (Greenfield, 2003; Krajka, 2002; Gonglewski, et al., 2001; Kupelian, 2001; Biensenbach, et al. 2001; Liao, 1999; Lee, 1998; Wang, 1998; Pillemer, 1997; Grosz-Gluckman, 1997; Belisle, 1996).

Going more in depth, groups were compared in each subcategory of writing performance. Based on the obtained results (as table 2 depicted), no significant differences $(p>.05)$ were found in terms of content, organization, vocabulary and mechanics when two groups of e-mail and pen-and-paper dialogue journal were compared; however, a significant difference $(p<.05)$ in terms of language use was identified between groups.

Earlier research-based studies had controversial results in the effectiveness of using e-mail in enhancing writing performance components. The finding of this study is consistent with the results of Shang's (2007) findings which showed that e-mail helped students to improve their writing performance in terms of syntactic complexity and grammatical accuracy. The results also is consistent with Albakri, et al.'s (2003) study which showed that students could qualitatively improve their content, language and vocabulary. Similarly, a research by Hung (2007) also showed Taiwanese college students corresponding through e-mail with their American key pals as compared to those who did not correspond through e-mails, could facilitate their overall writing ability especially in terms of fluency in writing. However, the results contradicts the results of studies by Stockwell (2005) and Gonzales-Bueno, et al. (2000) which revealed that e-mail did not affect lexical and grammatical improvement of learners.

\section{Conclusion}

Warschauer and Meskill (2000) suggested that language educators' focus in teaching the rules of grammar should be on investigating the methods in providing apprenticeship and joining them to a new community. As such, the internet can be viewed as a tool which has been successfully woven into the communicative approach.

To sum up, the benefits of e-mail in writing classes was documented in this study. The results of this study 
supported Hawisher and Moran (1993)'a point of view about e-mail:

We writing teachers need to pay attention to e-mail in our writing classes because it is here, because it is a means of written communication, and because we as academics are using it. E-mail, we believe, deserves a place in the curriculum (1993; p. 638).

\section{Implication}

The purpose of this study was to compare two different tools in writing dialogue journals. The findings of this study have important implications for educators, curriculum designers, students and those conducting research in ESL context. The results of this study may encourage ESL educators to implement e-mail dialogue journal in writing classes as a method to enhance writing performance. This study provided valuable insights into how communicative approach as a substitute of extra stress on error and grammatical correction could be applied in teaching writing. Unnecessary emphasize on grammar and error correction may cause anxiety and makes students reluctant to write. E-mail dialogue journal writing as suggested by many researches, including this current research, attested that it has potential in enhancing writing performance.

The inclusion of e-mail in writing dialogue journal in this study provided a guide for educators on how e-mail can be a useful tool and how it can be integrated in the ESL curriculum. Such integration in an electronic environment helps educators to have more control over students' learning in outside of school environment.

The findings of this study indicated that students could benefit from e-mail. Before starting the experiment, the demographic questionnaire revealed that students were unaware of the benefits of using e-mail in enhancing their learning. This study provided a practice for the participants involved and probably all ESL learners to view e-mail as an instructional tool rather than just a simple box to send and receive greetings and other information. Using dialogue journal writing whether via conventional tools or e-mail, gave students an opportunity to use the language without being afraid of getting penalized for making errors.

The findings of this study also have important implications for further research opportunities in the ESL or other L2 contexts. As stated earlier, although there are many studies on using dialogue journal writing for different contexts, there are only a handful of studies on utilizing e-mail dialogue journal especially in teaching and learning writing performance. Hence, the findings obtained in this study on the effectiveness use of e-mail dialogue journal to enhance writing performance would open new possibilities for further studies other than the ESL context.

\section{Suggestions of Further Studies}

After conducting the current research, the researcher considered some possible suggestions for further research. As effects of e-mail on enhancing writing performance was observed in this study, more research can be conducted to investigate the effects of e-mail on other language skills such as; speaking and reading. Data collection in this research was done during seven week period; as such, duration can be extended to one semester for more observable effects and results to take place. Dialogue journal as studied by some researchers has been considered as having both features in spoken and written discourse (Lingley, 2005). In addition, some researchers recognize e-mail as a tool that has features in both spoken and written discourse (Biesenbach-Lucas, 2000, 2001). In fact both dialogue journal and e-mail encompass unplanned discourse found in spoken skills. Thus, the effect of e-mail in improving speaking skills via dialogue journal can also be investigated.

\section{References}

Aitsiselmi, F. (1999). Second language acquisition through email interaction. ReCALL, 11(2), 4-11. http://dx.doi.org/10.1017/S0958344000004900

Albakri, I. S., Stepa, H., \& Din, R. (2003). Using E-mail dialogue writing In ESL Classroom: A Case Study. VirTEC Journal. 3(1), 1-13.

Ary, D., Jacobs, L. C., \& Razavieh, A. (2002). Introduction to research in education. Wadswoth, Thomas Learning

Barker, P. (2002). On being an online tutor. Innovations in Education and Teaching International, 39(1), 3-13. http://dx.doi.org/10.1080/13558000110097082

Baron, N. S. (2003). Why E-mail looks like speech-proofreading ,pedagogy ,and public face. In J. Aitchison, \& D. Lewis (Eds.), New Media Language (pp. 102-113). London: Rotledge.

Belisle, R. (1996). E-mail activities in the ESL writing class. The Internet TESL Journal, 2(12).

Biesenbach-Lucas, S., \& Weasenforth, D. (2001). E-mail and Word Processing in the ESL Classroom: How the 
medium affects the message. Language Learning and Technology, 5(1), 135-165.

Burley, H. (1994, January). Postsecondary novice and better than novice writers: The effects of word processing and a very special computer assisted writing lab. Paper presented at the Southwestern Educational Research Association Meeting, San Antonio, TX.

Chen, Y., Liu, C., \& Wong, R. (2007). The adoption of synchronous and asynchronous media in the teaching of a second language. Issues in Information Systems, 8(1), 217-223.

Crystal, D. (2001). Language and the Internet. Cambridge: Cambridge University Press. http://dx.doi.org/10.1017/CBO9781139164771

Daiute, C. (1986). Physical and cognitive factors in revising: Insights from studies with computers. Research in the Teaching of English, 20, 141-159.

Ferris, D. R., \& Hedgcock, J. S. (2005). Teaching ESL composition: Purpose, Process, and Practice (2nd ed.). Mahwah, N.J.: Lawrence Erlbaum.

Foroutan, M., \& Nooreen, N. (2012). Effect of dialogue Journal writing through the use of conventional tools and e-mail on writing anxiety in the ESL context. English Language Teaching, 5(1).

Fox, G. (1998). The Internet: making it work in the ESL classroom. The Internet TESL Journal, 4(9).

Garlikov, R. (2000). Significant Differences Between Writing and Talking: Why Talking Seems Easier. Retrieved June 21, 2007, from http://www.garlikov.com/talkwrite.htm

Gonglewski, M., Meloni, C., \& Brant, B. (2001). Using E-mail in foreign language teaching: rationale and suggestions. The Internet TESL Journal, 7(3).

Gonzalez-Bueno, M., \& Perez, L. C. (2000). Electronic Mail in foreign language writing: A study of grammatical and lexical accuracy, and quantity of language. Foreign Language Annals, 33(2), 189-198. http://dx.doi.org/10.1111/j.1944-9720.2000.tb00911.x

Greenfield, R. (2003). Collaborative e-mail exchange for teaching secondary ESL: A case study in Hong Kong. Language Learning \& Technology, 7(1), 46-70.

Grosz-Gluckman, V. (1997). A look at the use of electronic mail (e-mail) as a learning tool in the writing skills of adult LEP Female Students.

Hawisher, G. E., \& Moran, C. (1993). Electronic mail and the writing instructor. College English, 55(6), 627-643. http://dx.doi.org/10.2307/378699

Hawisher, G., \& Fortune, R. (1988). Research into word processing and the basic writer. Paper presented at the annual meeting of the American Educational Research Association, New Orleans, LA. (Available ED 298 943).

Hein, G. (1991). Constructivist Learning Theory. CECA (International Committee of Museum Educators) Conference. $\quad$ Retrieved $\quad$ May $\quad$ 2007, from http://www.exploratorium.edu/ifi/resources/museumeducation.html

Holmes, V. L., \& Moulton, M. R. (1997). Dialogue journals as an ESL learning strategy. Journal of Adolescent and Adult Literacy, 40, 616-621.

Hung, P. Y. (2007). The effects of Exchanging E-mails with American key pals on Taiwanese college students' writing in English. Unpublished doctoral dissertation, Kent state University College.

Jacobs, H. L. Zinkgraf, S. A., Wormuth, D. R., Hartfiel, V. F., \& Hughey, J. (1981). Testing ESL composition: A practical approach. Rowley, MA: Newbury House.

Kern, R. G. (1995). Restructuring classroom interaction with networked computers: Effects on quantity and characteristics of language production. Modern Language Journal, 79(4), 457-476. http://dx.doi.org/10.1111/j.1540-4781.1995.tb05445.x

Kim, J. (2005). A community within the classroom: dialogue journal writing of adult ESL learners. Adult basic education, 15(1), 21-32.

Kitao, S. K. (1998). Interaction and on-line synchronous communication in English language. CALL-EJ.

Krajka, J. (2002). Using the internet in ESL writing instruction. The Internet TESL Journal, 4(11).

Krashen, S. D. (1982). Principles and Practice in Second Language Acquisition. Pergamon Press Ltd., England. 
Kroonenberg, N. (1994-1995). Developing communicative and thinking skills via electronic mail. TESOL Journal, 4(2), 24-27.

Kuhlman, N. A. (1993). Emerging literacy in a two-way bilingual first grade classroom. In L. M. Malave (Ed.), Annual Conference Journal. Washington D.C. ERIC.

Lam, F. S., \& Pennington, M. C. (1993). The Computer vs. the Pen: A Comparative Study of Word Processing in a Hong Kong Secondary Classroom. Computer-Assisted Language Learning, 8(1), 75-92. http://dx.doi.org/10.1080/0958822950080106

Lee, E. K. (1998). Using E-mail in EFL Writing Classes. The Internet TESL Journal, 4(11).

Liao, C. C. (1999). E-mailing to Improve EFL Learners' Reading and Writing Abilities: Taiwan Experience. The Internet TESL Journal, 5(3).

Lightfoot, J. M. (2006). A comparative analysis of e-mail and face-to-face communication in an educational environment. Internet and Higher Education, 9, 217-227. http://dx.doi.org/10.1016/j.iheduc.2006.06.002

Lingley, D. (2005). Spoken features of dialogue journal writing. Asian EFL Journal, 7(2).

Ministry of Education Malaysia. (2004, July 31). The Development of Education. National Report of Malaysia by Ministry of Education. Retrieved September, 2008, from: http://www.ibe.unesco.org/International/ICE47/English/Natreps reports/malaysia.pdf

Mynard, J. (2003). Synchronous computer-mediated communication and learner autonomy in female Emirati learner of English. Unpublished doctoral dissertation, university of Exeter, United Kingdom.

Ohlund, B. (1997). Constructivism and CMC: The Importance of Constructivist Approach in Computer-Mediated Communication. Retrieved May 15, 2008, from http://seamonkey.ed.asu.edu/ mcisaac/emc70old97/spring97/7/ohl7.htm

Peyton, J. K. (1984). Dialogue writing: Bridge from talk to essay writing. Language Art, 61(2), 141-150.

Peyton, J. K. (1990). Dialogue journal writing and the acquisition of English grammatical morphology. ERIC.

Peyton, J. K. (2000). Dialogue Journals: Interactive Writing to Develop Language and Literacy. Retrieved April 16, 2007, from http://www.cal.org/caela/esl_resources/digests/Dialogue_Journals.html

Peyton, J. K., \& Reed, L. (1990). Dialogue journal writing with nonnative English speakers: A handbook for teachers. Alexandria, VA: Teachers of English to Speakers of Other Languages.

Pillemer, J. (1997). E-mail as a teaching tool. Retrieved March 15, 2006, from http://www.etni.org.il/jack.htm

Razak, R., \& Asmawi, A. (2004). The use of Dialogue Journal through E-mail Technology in Developing Writing Internet and Skills. Malaysian Online Journal of Instructional Technology, 1(2), 14-24.

Reid, L. (1997). Exploring the ways that dialogue journaling affects how and why students write: An action research project. Teaching and Change, 5(1), 50-57.

Romiszowski, A., \& Mason, R. (2004). Computer-mediated communication. Retrieved May 25, 2007, from http://www.aect.org/edtech/15.pdf

Shang, H. F. (2007). An Exploratory Study of E-Mail Application on FL Writing Performance. Computer Assisted Language Learning, 20(1), 79-96. http://dx.doi.org/10.1080/09588220601118479

Soh, B. L., \& Soon, Y. P. (1991). English by e-mail: creating a global classroom via the medium of computer technology. ELT Journal, 45(4), 287-292. http://dx.doi.org/10.1093/elt/45.4.287

Song, M. (1997). The effect of dialogue journal writing on writing quality, reading comprehension, and writing apprehension of EFL college students.

Stockwell, G. (2005). Syntactical and lexical development in NNS-NNS asynchronous CMC. The JALT CALL Journal, 1(3), 33-49.

Sullivan, N., \& Pratt, E. (1996). A comparative study of two ESL writing environments: A computer- assisted classroom and a traditional oral classroom. System, 29(4), 491-501. http://dx.doi.org/10.1016/S0346-251X(96)00044-9

Vacc, N. N. (1987). Word processor versus handwriting: A comparative study of writing samples produced by mildly mentally handicapped students. Exceptional Children, 54(2), 156-165.

Wang, Y. M. (1998). E-mail dialogue journaling in an ESL reading and writing classroom. International JI. of 
Educational Telecommunications, 4(2-3), 263-287.

Warschauer, M. (2002). Networking into academic discourse. Journal of English for Academic Purposes, 1(1), 45-58. http://dx.doi.org/10.1016/S1475-1585(02)00005-X

Warschauer, M. (2004). Technology and writing. In C. Davison, \& J. Cummins (Eds.), Handbook of English Language Teaching. Kluwer, Dordrecht, Netherlands.

Warschauer, M., \& Healey, D. (1998). Computers and language learning: An overview. Language Teaching, 31, 57-71. http://dx.doi.org/10.1017/S0261444800012970

Warschauer, M., \& Meskill, C. (2000). Technology and second language learning. In J. Rosenthal (Ed.), Handbook of undergraduate second language education (pp. 303-318). Mahwah, New Jersey: Lawrence Erlbaum.

Warschauer, M., (1996). Comparing face-to-face and electronic discussion in the second language classroom. CALICO Journal, 13(2), 7-26.

Warschauer, M., Shetzer, H., \& Meloni, C. (2000). Internet for English teaching. Alexandria, VA: TESOL Publications.

Wen, L. M., Tsai, C., Lin, H., \& Chuang, S. (2003). Cognitive-metacognitive and content-technical aspects of constructivist Internet-based learning environments: a LISREL analysis. Computers \& Education, 43, 237-248. http://dx.doi.org/10.1016/j.compedu.2003.10.006

Whittaker, S., \& Sidner, C. (2000). E-mail overload: exploring personal information management of e-mail. Retrieved November 17, 2007, from http://dis.shef.ac.uk/stevewhittaker/emlch96.pdf

Wolff, D. (1999). M. Levy: Computer-Assisted Language Learning. Context and Conceptualization. System, 27(1), 125-128.

Woolfolk, A. E. (2007). Educational psychology. Pearson Education, Inc.

Worthington, L. (1997). Let's Not Show the Teacher. EFL Students' Secret Exchange Journals. Forum, $35(3), 2$.

Yen-Ren, T. (1996). Group Reading Diary. Forum, 34(3), 63.

\section{Copyrights}

Copyright for this article is retained by the author(s), with first publication rights granted to the journal.

This is an open-access article distributed under the terms and conditions of the Creative Commons Attribution license (http://creativecommons.org/licenses/by/3.0/). 